\title{
Same Principles but Different Outcomes of SAARC and ASEAN: Searching Gap
}

\author{
Mohammad Razaul Karim \\ Ph.D. Student, International Politics \\ School of Political Science and Public Administration \\ Shandong University \\ Jinan, Shandong, P. R.China \\ Assistant Professor \\ Department of Public Administration \\ Comilla University, Comilla-3503, Bangladesh \\ E-mail: razaul_karim16@yahoo.com
}

Received: Jan. 25, 2019 Accepted: Feb. 18, 2019 Online published: Feb. 25, 2019

doi:10.5296/jpag.v9i1.14266

URL: https://doi.org/10.5296/jpag.v9i1.14266

\begin{abstract}
This article shows that two regional organizations- the Association of South East Asian Nations and the South Asian Association for Regional Cooperation were established for regional cooperation and integration. Though both regional organizations' principles, objectives have similarity but unfortunately, SAARC became an ineffective organization by failing to achieve its goal. Intra-regional trade of SAARC is significantly worse than other regions in the globe. This article tries to find out the reason behind the ineffectiveness of SAARC and concludes that India-Pakistan rivalry, India's role with smaller countries and mutual mistrust among the nations of South Asia are the main causes that made SAARC an ineffective organization. On the contrary, ASEAN nations have practiced informal diplomacy to mitigate their bilateral disputes, decision making process- the ASEAN way, Indonesia's positive role made ASEAN a successful organization. The article has also shown a comparative analysis between SAARC and ASEAN for identifying some good examples which SAARC countries could follow.
\end{abstract}

Keywords: SAARC, ASEAN, Role of the Larger State, Conflict Management 


\section{Introduction}

In the age of globalization, states are more concentrating on regional cooperation for their countries development. The growing aptitude of regionalism assists to address social, economic, and political issues. A regional organization can be the best way to ensure peace and stability as well as increase mutual cooperation of that region. The Association of South East Asian Nations (ASEAN) and the South Asian Association of Regional Cooperation (SAARC) are two different regional organizations in Asia that were established to increase regional integration in the respective region. As a region, South Asia covers a total area of $5,099,611 \mathrm{sq}$. Km, and a staggering population of 1.713 billion, which is over 20 percent of the world's population, and a combined GDP US \$9.9 trillion, nominal GDP US \$2.9 trillion. Its Worldwide Foreign Direct Investment (FDI) is three percent and its contribution to the world trade is only two percent (Hafeez, 2016). Though SAARC was established to increase regional integration of South Asia, regrettably, this organization did not perform adequately. For that reason, it is noticeable that intra-regional trade is very poor. For example, Sally argues that: "Intra-regional trade as a share of the region's total trade is $4 \% \ldots$. It represents about $2 \%$ of regional GDP, compared to the above 30\% in East Asia” (Sally, 2010, p. 4).

SAARC is seen as an oral wizardry of speech of the responsible persons of its member countries; but in practice, it suffers political instability, trust deficit among them (Majid, 2011). SAARC has failed to achieve its goal due to weak regional political leadership, India's hegemony and its disputes with most of the countries. Even after 72 years of independence of many countries of the South Asian region, they failed to build an effective organization as well as solve their regional problems. On the contrary, ASEAN is observed as an ideal organization for regional peace, stability, and prosperity. The ASEAN, total covers a land area of 4.3 million square $\mathrm{km}$. ( $3 \%$ of the total land area of the world), the total population of approximately 634 million. ASEAN's combined GDP had reached at USD 2.55 trillion in 2016, and it became the sixth biggest economy in the world ("ASEAN: A regional profile", 2018). ASEAN member states formulate policies for ensuring its regional cooperation rather than state centric benefits (Majid, 2011). Intra-regional trade among SAARC member states has continued nearly the same over the years, only between 4 to 8 percent, whereas ASEAN inter-regional trade has reached between 23 to 27 percent. According to the World Bank [WB] (2018b), Intraregional trade in East Asia and the Pacific accounts for 50 percent of its total trade, whereas in South Asia, it accounts for only 5 percent of its total trade, and 22 percent in Sub-Saharan Africa.

\section{An Overview of SAARC and ASEAN}

SAARC was established on December 8, 1985, 'to promote the welfare of the people of South Asia, to accelerate economic growth, social progress, and cultural development, strengthen collective self-reliance and to promote active collaboration in the various fields of South Asian states'. SAARC exposed on the world stage as a regional organization due to boundless efforts of Bangladesh. This organization started a journey with seven South Asian countries: Bangladesh, India, Pakistan, Nepal, Sri Lanka, Maldives, and Bhutan. In 2007 during the $14^{\text {th }}$ summit, Afghanistan became a member of it whereas China, Myanmar, The 
United States and the European Union (EU) got the observer status of this organization (Hafeez, 2016). Among eight members of SAARC countries, India is the largest member states in terms of economy, size, population and military power. India is the only powerful country who has appeared as the fourth most powerful military in the world. India has common land broader with all countries except Afghanistan, and interestingly, all countries face border dispute with India. Unequal distribution of power, India Pakistan rivalry, and India's regional security doctrine perceived mutual threat perceptions to other smaller countries of this region and raised severe challenges to their political survival as sovereign states (Chakma, 2009); which ultimately hampered SAARC regular activities. The SAARC summit held once in a year. Till 2018, SAARC has held $19^{\text {th }}$ summits and more than hundreds of ministerial and secretarial level meetings. In each summit, the leaders of the countries restate their past declarations in a new way and iterate their commitments. SAARC has got partial progress of its stated goal of enhancing trade and investment with the execution of SAARC Preferential Trading Agreements (SAPTA) (Siddiqi, 2015).

ASEAN was formed on 8 August 1967 in order to ensure internal political solidity within member countries against both intra-regional and external intervention by Indonesia, Malaysia, Philippines, Singapore and Thailand (Acharya, 1998; Shee, 1997). Later the bloc has been increased by the joining of Brunei, Vietnam, Myanmar, Laos, and Cambodia. ASEAN was established in the middle of the Vietnam War (also recognized as the Second Indochina War) in 1967 against the growing potential threat of communist-led insurgence (Ginsberg, 2009). Therefore, at the very beginning of ASEAN establishment, though it was a formal regional organization but it was recognized as an anti-communist block. During the ASEAN establishment, the region suffered underdevelopment, long-standing instability, and inter-state clashes. Their continuing conflict had an impact of their policies in the early stages. The original situations is described by Thambipillai \& Saravanamutta as follows

When the original five members of the organization -Indonesia, Malaysia, the Philippines, Singapore, and Thailand -signed the Bangkok Declaration in 1967, they had little in common apart from climate and natural resources and somewhat similar ideological orientation. Apart from diversity in language, religion, and ethnic identity, these nations were isolated from each other politically and economically (linked separately to western metropolis) despite geographical and semblance of cultural bonds. (Thambipillai \& Saravanamutta, 1985, p.3)

The key aims of ASEAN are to speed up cooperation in the economic growth, socio-cultural development in the region and to uphold regional peace and solidity through adhering to the values of United Nations Charter, respect for justice and spirit of the rule of law. The ASEAN summit usually held once in two years.

Though South Asian countries share strong cultural similarities among them but it is also distinct by the presence of boundless disparities which hardly exist in any other part of the world. The eight countries of SAARC are not equal in status, population, size, ownership of natural resources and the level of economic growth. Such types of contrasts have not become favorable to the progress of regional collaboration in South Asia (Grover, 1997). On the other 
hand, ASEAN members do not share such strong similarities or differences as found in the case of SAARC.

\subsection{Principles of SAARC and ASEAN}

If we considered the principal of ASEAN and SAARC, there is no fundamental distinction between them. The ASEAN Member States shall act in accordance with the following fundamental principles, as enclosed in the Treaty of Amity and Cooperation in Southeast Asia (TAC) of 1976: 1. Mutual respect for the independence, sovereignty, territorial integrity, equality and national identity of all nations; 2 . Every member state has the right to lead its national existence free from outside intervention, subversion, and oppression; 3 . The right of every State to lead its national existence free from external interference, subversion or coercion; 4. Non-interference in the internal matters of ASEAN Member Countries; 5. Dependence on a peaceful settlement of disputes or differences; 6. Effective cooperation among the ASEAN member states (ASEAN, n.d.).

Like ASEAN, four such rules were enclosed in the first meeting of the foreign secretaries of SAARC member countries 1. Co-operation within the framework of the SAARC on the basis of respect for the values of sovereign equality, political independence, territorial integrity, non-interference in the internal matters of other states and mutual benefits. 2. Decisions at all stages of SAARC to be taken based on unanimity. 3. Bilateral and contentious issues are omitted from the SAARC discussions. 4. Regional co-operation should not be a substitute or inconsistent with bilateral or multilateral obligation but could complement both (SAARC, n.d.). If any country considers any aspect is incompatible with its national interests, respective country can give a veto to refuse that area or point.

Although both ASEAN and SAARC had the determination to protected peace, prosperity, stability, and socio-cultural development but ASEAN has undoubtedly stepped ahead in this regard.

\subsection{Interregional Trade}

Intra-regional total goods trade in South Asia amounts to USD 23 Billion currently, but, according to the World Bank report, "gravity models claims it could be worth \$67 Billion". This wide gap between actual and potential trade arises due to discrimination of South Asian Countries among each other (World Bank, 2018c). There are many causes to lower Intraregional trade; one of the most important reasons is the higher cost of trade within South Asia in comparison to other regions. The average tariff is over and above double in South Asia compared with the world average. The average tariffs were 13.6 percent in South Asia in 2016, whereas the world average tariffs were 6.3 percent (World Bank, 2018b). Due to lack of proper transportation system, logistics infrastructure, and complex as well as non-transparent non-tariff measures drives the excessively high costs of trading in South Asia. For instance, Sri Lanka needs to spend more money to trade with Nepal than with Brazil (World Bank, 2018c). SAARC countries required average 106 hours for imports within the region whereas ASEAN countries need only average 83 hours (Hasan, Malik, Khan, \& Anwar, 2017). In spite of the existence of the SAFTA (Free Trade Area), trading within the region is 
not free. This has happened mainly for the long sensitive lists of products which were not incorporated under the concessional tariff of SAFTA. In the case of Bangladesh, approximately 46 percent of its imports from the South Asia region flow into sensitive lists (World Bank, 2018a). In the perspectives of Sri Lanka, almost 44 percent of imports and 23 percent of its exports to the region falls under the sensitive list. South Asian countries imposed high tariffs and para-tariffs, although for tariff liberalization, SAARC countries made SAFTA. Only specific categories of VIP get Visa exemption to visit SAARC countries, and ordinary citizen faces difficulties to get visa especially for traveling to India. It is hard to get a visa for Pakistanis to enter India and vice versa. Even other SAARC countries citizens who already have visited either India or Pakistan, now desire to travel to the other, face harassment by either country's visa issuing authority (Archana, 2017). The citizens of ASEAN countries need not required a visa to move amongst the member nations.

\section{Purpose and Research Question}

It is observed that SAARC and ASEAN, both regional organizations' objectives and principles are quite the same. When these organizations were established, the socio-economic conditions were also similar between the ASEAN and SAARC member countries. But it is clear that intraregional trade and efficiency of ASEAN is better than SAARC. That is why, my study aims to find out the reasons that made SAARC ineffective. To serve my purpose I have set a research question- Why did SAARC fail to achieve its goals and how did ASEAN get success in comparison to SAARC?

\section{Research Method}

The study is a qualitative analysis based on secondary sources. Secondary data collected from various reliable sources such as specialists' books and journal articles related to SAARC and ASEAN. International and national newspapers also have been studied. In addition, working papers, research papers, policy papers, and various related organizational website data had been used to complete this study.

\section{Discussion and Analysing}

\subsection{Decision Making Process}

In the SAARC, the decision is based on 'unanimity' which allows any member veto power to refuse any aspect or area that is considered to unharmonious with its national interest. Moreover, the charter of SAARC has a provision that 'bilateral and contentions issues' is prohibited from discussing at SAARC summits. Undoubtedly, bilateral disputes are the main troublesome factor for the ineffectiveness of SAARC. If the members are not allowed to negotiate the bilateral disputes frankly and widely, not only the atmosphere will be hampered but also the socio-economic objectives will not be achieved in this region. SAARC members are different in power, size, and economy along with border disputes with one another which is an obstacle in taking decisions unanimously (Shaheen, 2013). Due to decision making process, SAARC has remained infirm, but there is no initiative to amend these provisions regarding a discussion on bilateral disputes in SAARC. In this circumstance, SAARC cannot run soundly, and it is far away to achieve its goal. 
In the ASEAN, a decision is based on Consensus which means cooperation could only progress when it is realized to be comfortable to all. If any member feels any regional proposal is threating to its national interest, she can apply veto power on that proposal. It is neither indicated unanimity per se, nor does it include voting, as not all members of ASEAN essential to agree perceptibly with the proposal under discussion; though it does need enough support to approve a proposal (ASEAN documents do not cite a specific member) and it is required to ensure that no member votes against it. (Severino, 2006). ASEAN introduce "consensus minus X principle in ASEAN Way" which means a member country is allowed to give up participation in a plan or scheme without impeding others. For instance, ASEAN Free Trade Area was set up by Malaysia, Indonesia, and Singapore, whereas comparatively less developed countries such as Laos, Cambodia, Myanmar and Vietnam were granted more time to enforce the reforms which were essential to participate. In case of a deadlock like a diversity of opinions and interests among governing leaders, along with unresolved territorial disputes and political differences, member has option to bilateral negotiations (Feraru, 2015). Thus consensus decisions are reached at through consultations between governments.

\subsection{Conflict Mitigating Process}

One of the vital reasons to set up ASEAN and SAARC was that to mitigate conflict between the countries as they were involved in serious disputes. In the comparison of contradictory issues of both organization, ASEAN members were faced more problem because of its conglomeration of islands and nuclear laws dealing with maritime boundaries. Unfortunately, SAARC was not able to avoid conflict, while ASEAN was succeeded. What was the root cause? Some think while ASEAN members considered communism (external countries) as a threat, where South Asian countries were looking for enemies was within-India. Nevertheless, ASEAN members had boundary disputes with one other but they decided to forget. For example, ASEAN consensus was challenged due to the Philippines-Malaysia clash over Sabah, but the founding nations got a peaceful way to lessen opposing claims.

ASEAN members have abstained from displaying visible antagonism against each other and have attempted to resolve discord through cooperation, negotiation, and engagement. When ASEAN was denounced for accepting Myanmar notwithstanding its military rule, but the organization thought, putting emphasize on keeping up open communication and engagement with it is a better way to influence the regime (Archana, 2017). Hoang Anh Tuan (1996) argued ASEAN has succeeded in dispute management by applying five techniques: 1. Adherence to the basic rules, regulations, and declarations of ASEAN 2. They are emphasizing the virtue of will power 3. To resolve disputes sometimes using third party mediation 4. A decision is based on consultation (musyawarah) and consensus (mufakat) 5. Agreeing to distress or defer disagreements for a future settlement. On the contrary, SAARC members emphasized to mitigate broader dispute before economic cooperation starts in full swing (Ahmed, 2011). SAARC never introduced a formal strategy for managing conflict in South Asia. Instead, it was mostly concentrated on increasing economic and socio-cultural cooperation in the region. Overall while ASEAN members tried to avoid or solve a conflict, SAARC declined to discuss bilateral disputes. Whereas ASEAN has acted rationally and sensibly, SAARC countries have been obstructed by bilateral unfriendliness and the wicked 
legacy of partition.

\subsection{Informal Diplomacy}

Actually, when ASEAN was inaugurated, the word 'association' was meant to separate it from an organization; thus it carried a flexible style and a perception of informality. While confrontation and malice are observed between the countries, at that time personal relations and direct conversation between the leaders were considered more effective than formal diplomacy. The former Foreign Secretary of the Philippines Mr. Carlos Romulo said, "We often find that private talks over breakfast prove more important than formal meetings" (Collins, 2003). For example, Water treaties Between Singapore and Malaysia, Temasek Holdings' investment in the Thai telcom Shin Corp between Singapore and Thailand, dispute between Thailand and Cambodia over the ownership of the famous Preah Vihear temple- it is observed that conflicts were effectively managed through the informal and quiet diplomacy in the South East Asian region (Rahman, 2011). The 'ASEAN way' is the significant aspect of ASEAN by which confrontational issues are avoided. ASEAN emphasizes the idea of quiet diplomacy that means where differences are exposed and compromises are required; then negotiations start at an informal way. When any contentious issue is raised, and it is impossible to compromise even it provokes to confront, such type of issues are dropped from the agenda. Thus ASEAN emphasizes conflict avoidance rather than resolving among its members (Beukel, 2008).

On the other hand, SAARC countries leader are not used practicing informal diplomacy. Most of the countries think that the SAARC charter should be amended so that bilateral issues can be discussed in SAARC. They believe that without resolving the political issues, economic cooperation cannot be achieved. On contrary, India think that if bilateral issues are allowed to discuss in SAARC, smaller states might be shaped a united front to tackle India (Choquier, 2010).

\subsection{Nuclear Free Zone}

ASEAN five original members met in Malaysia and signed Zone of Peace, Freedom and Neutrality (ZOPFAN) declaration on November 27, 1971, to keep free from the external interference and broaden cooperation in Southeast Asia. ASEAN's ultimate target was the establishment of Nuclear-Weapon-Free Zone. It was taking time due to rivalries among the members, adverse political situation and the Cold War. However, in 1995, the head of government of 10 ASEAN member states signed the Southeast Asian Nuclear Free Zone (SEANWFZ) treaty in Bangkok for establishing a nuclear weapon free region. Though the Philippines had not ratified the treaty, it was effective on 28 March 1997. The Philippines ratified it on June 21, 2001 and after that in this region all nuclear weapons were banned effectively. There is a commission to review the progress on the implementation of the action plan for the year of 2013-2017. (Ministry of Foreign Affairs, 2014). Therefore, this treaty creates an optimistic development of peace and harmony in the long run as well as inspiring process for the ultimate success of the global nuclear and disarmament.

SAARC is unsuccessful to uphold a balance of political, economic and military interests of 
member states. Whereas ASEAN declared East Asia is a nuclear-free zone, two South Asian countries are competing to increase nuclear weapons there. In May 1998, both India and Pakistan tested their nuclear weapons which intensified their hostility and proliferations regional tension and it is reflected in almost every SAARC summit. Actually, ongoing hostilities and mutual suspicion between India-Pakistan relations lie at the root of all worries in South Asia (Dwivedi, 2003); thus it hampered South Asian regional integration as well.

\subsection{Role of the Largest State}

Indonesia is the biggest state in size and population among the South- East Asian countries. It was a founding member of ASEAN - which played a significant role in the formation of ASEAN and the nurturing of regional integration (Heiduk, 2016). Before the establishment of the ASEAN, South East Asian nations were suspicious and felt fear towards Indonesia. But the leadership of Suharto provided to ASEAN played an important role that is a key strength in keeping ASEAN organized till today. The Confrontation or Konfrontasi between Malaysia and Indonesia continued from 1963 to 1966. Indonesia under the leadership of Suharto mitigated the conflicts in 1967. He noticed ASEAN as the accurate apparatus to tackle the stained image of post-"konfrontasi" Indonesia. After the establishment of ASEAN, Jakarta became prominent on cooperation as well as showing self-restraint rather than coercive act to retain the trust of neighbouring countries (Sukma, 2012). Indonesia sought to expose itself as a peaceful, moderate, and responsible partner in the region and beyond (Leifer, 1983). Regional integration was perceived as an instrument to raise peaceful, cooperative dealings with Indonesia's neighbours. Hence, Indonesia was eager to take up the role of a trustworthy regional leader. Similarly, smaller states of ASEAN were also willing to mingle with Indonesia and started to show some respect as the regional leader. For example, in 1968, Singapore hanged two Indonesian commandoes but Indonesia's response was non-aggressive in spite of peoples demonstration in Jakarta. In turn, as a reconciliatory gesture, Prime Minister of Singapore Lee Kuan Yew visited Indonesia in 1973, during this time he spread flower petals on the graves of the commandos (Rahman, 2011).

On the other hand, although India, as the largest in size, population, military, and economy in South Asia, it did not play a rigorous role in the proposed regional organization like Indonesia. Indeed, when Bangladesh President proposed to establish a regional organization in South Asia, India was indecisive towards the organization and thought it would be a forum where the smaller nations could 'gang up' against it (Thornton, 1991). India considers South Asia as a sphere of influence of her and is looking for a leadership position for herself, whereas South Asian countries blame her of exercising domination. Almost all South Asian countries perceived a threat from India and bilateral relations also hampered because of its hegemonic attitude. India continuously interferes in the internal matters of smaller states. Almost all South Asian countries have border conflict with India except Maldives and Sri Lanka and all countries wish to resolve the border dispute bilaterally but India emphasizes coercive rather than cooperation. Though India believes that her neighbor states are sovereign, but she has developed a regional security doctrine so that her neighbours keep away from extra-regional powers for security related issues. According to this doctrine, India has no wish to interrupt in her neighbouring countries internal matters, but if any countries of this region require 
external security support, they should request no one but India otherwise they will be considered as 'anti-Indian' (Gupta, 1983). India implemented its regional security doctrine minimum three times in the 1980s; for example, to resolve the ethno-national conflict in Sri Lanka, New Delhi commenced a peace keeping operation in 1987 though it failed; in 1988, it helped Maldives government by providing military support; and in 1989, it enforced an economic blockade against Nepal because of a clash over transit treaties and its apprehension over Nepal's growing close strategic relations with China (Chakma, 2009). India's neighbors considered such type of regional security doctrine as a threat to their political existence as sovereign states. Pakistan perceived it as a clear hegemonic expression of India. Moreover, Sri Lanka, Nepal and Bangladesh are anxious about the doctrine's implications for their independence. As a landlocked country, Nepal needs to use India's territory for its trade with other countries in the world. India makes hindrance when it is not happy with Nepal's policy. Whenever Nepal declared itself as a zone of peace, India was unwilling to endorse it. Moreover, India has water sharing clashes with Bangladesh and Nepal. India's aspiration to play a vital role as a leader in the decision making process of the region without taking any responsibility which generated concerns among the adjacent countries mainly Pakistan, Bangladesh and Sri Lanka (Shaheen, 2013). Reza (2016) noted in his study, a Japanese diplomat who served a long time in the South Asia region said that India wanted to have some sort of problems all the time in its neighboring states. Because, if its neighbours suffered instability, it would privilege India to intervene. India has also apparently 'bypassed' SAARC and has enthusiastically involved with extra-regional multilateral organizations like BIMSTEC, ASEAN, East Asia Summit (EAS), and the ARF (Pattanaik, 2006).

\subsubsection{India Pakistan Relations and Impact on SAARC}

There is no confusion that India's conflictual relationship with her neighbours is the root cause of SAARC failure. Especially, Indo-Pak rivalry is the reason behind below standard of SAARC's performance. There are several issues such as Kashmir, Nuclear arms race, Siachen Glacier, cross-border terrorism etc. which makes the more complex nature of relations between India and Pakistan. Moreover, India accused that Pakistan provides support to the terrorists at Kashmir and Punjab. The growing mistrust between the two countries has also hampered SAARC regular activities (Nahar, 1991). From 1985 to 2016, total eighteen Summits have been held; on the contrary, fourteen SAARC Summits have been postponed because of the rejection of the member countries to join the Summits. Most of the SAARC Summit were postponed because of refusal to attend the head of state of Indian Government. Among them, the eight summits did not hold due to India-Pakistan rivalry (Ahmad, 2017). In 1994 the SAARC summit was not held due to the diplomatic and political embargo between the two countries for Kashmir issue. Again, India refused to attend the SAARC summit during 1999 to 2002, because in 1999, Kargil war happened between India and Pakistan, in the same year General Musharraf came to power through a military coup in Pakistan. During this time, India declined to participate in the summit mainly because her policymakers were suspicious that General Musharraf was the architect of the Kargil war though India's official position was that if PM of India visits Pakistan, the military coup of General Musharraf would became legitimate (Dash, 2008). In 2003, for the twelfth SAARC meeting host was 
Pakistan but in December 2002, she declared postponement of the schedule because India denied confirming participation and Islamabad thought Delhi of 'disrupting the event and adopting tricky methods to derail' the Summit. (Ahmad, 2017). India proposed to introduce South Asian Preferential Trading Arrangement (SAPTA) but Pakistan opposed. Later on, though Pakistan recognized SAPTA, she refused to approved the 'Most Favoured Nation (MFN) Status' to India, whereas India had reciprocated already (Ahmed, 2011). The SAARC summit 2016 did not held because of Uri attacked by terrorist in the Indian controlled Jammu and Kashmir. India suspected that the militant group Jaish-e-Mohammad was involved in the execution of the attack. The Ministry of External Affairs of India issued a statement stating, "India has conveyed to current SAARC Chair Nepal that increasing cross-border terrorist attacks in the region and growing interference in the internal affairs of Member States by one country have created an environment that is not conducive to the successful holding of the 19th SAARC Summit in Islamabad in November 2016." "In the prevailing circumstances, the Government of India is unable to participate in the proposed Summit in Islamabad," the statement said (“SAARC summit "postponed indefinitely"”, 2016).

\section{Conclusion}

As a regional organization, while ASEAN has fully-fledged from strength to strength, on the contrary, SAARC has gone retrograde. ASEAN nations have turned into more integrated through boosted intraregional trade and commerce as well as connectivity; SAARC countries were tending to be hostile. As a larger state, Indonesia has shown a positive attitude towards ASEAN since its establishment while India played a negative role from its founding to till now. It is noticeable ASEAN are conflicting avoidance nations. Trade has increased rapidly within ASEAN countries because it has emphasized no encouraging rapid economic development and modernization instead of involving disputes. Despite the strong pledge to multilateralism of ASEAN nations, bilateral approaches to security support and differences management remain significant characteristics of intra-ASEAN security affairs. South Asian countries political leaders should meet frequently and carry on informal dialogue along with formal discussion like ASEAN countries leaders to address their mutual problems. To start informal diplomacy, SAARC could choose less controversial issues at first like poverty reduction. Obviously, India and Pakistan should concentrate more to revitalize the regional organization; otherwise, it will become a utopian as well as a dysfunctional organization. India should keep in mind, being a global leader, it should maintain good relations with its neighbor; SAARC could serve a better platform for it. SAARC countries should emphasize minimizing sensitive lists and para-tariffs to make real progress of the region. SAARC countries could take the initiative to easier trade procedure and develop infrastructure. South Asian policy makers can follow ASEAN and East Asian initiatives which will serve them some useful reference tools for reforming SAARC.

\section{References}

Acharya, A. (1998). Culture, security, multilateralism: The ASEAN way and regional order. Contemporary Security Policy, 19(1), 55-84. https://doi.org/10.1080/13523269808404179 
Ahmad, M. (2017). SAARC Summits1985-2016: The Cancellation Phenomenon. IPRI Journal 17(1), 43-71. from www.ipripak.org/wp-content/uploads/2017/04/Article-No.-3w17.pdf

Ahmed, K. (2011, Apr. 16). Comparing SAARC and ASEAN. The Express Tribune. Retrieved from https://tribune.com.pk/story/150732/comparing-asean-and-saarc/

Archana. (2017, Nov. 24).Comparing ASEAN and SAARC in achieving their objectives, Why SAARC a failure over ASEAN? (Hindu Summary-24th Nov 2017). iasinsights. Retrieved from https://iasinsights.in/2017/11/24/comparing-asean-and-saarc-in-acheiving-their-objectives-wh y-saarc-a-failure-over-aseanhindu-summary-24th-nov-2017/

ASEAN. (n.d). ASEAN Overview. ASEAN. Retrieved January 14, 2019, from http://asean.org/asean/about-asean/overview/

ASEAN: A regional profile. (2018, Feb. 2). Eye on Asia, Retrieved from http://www.eyeonasia.sg/know-asean/overview-of-asean-countries/asean-regional-profile/

Beukel, E. (2008). ASEAN and ARF in East Asia's Security Architecture: The Role of Norms and Powers. DIIS Report 4, Denmark.

Chakma, B. (2009). South Asia's Realist Fascination and the Alternatives. Contemporary Security Policy, 30(3), 395-420. https://doi.org/10.1080/13523260903326404

Choquier, C. (2010). ASEAN and SAARC: Resolving Intra Regional Disputes. Institute of Peace and Conflict Studies.

Collins, A. (2003). Security and South East Asia: Domestic, Regional and Global Issues. Institute of Southeast Asian Studies, Singapore.

Dash, K. C. (2008). Regionalism in South Asia Negotiating cooperation, institutional structures (Vol.8). Routledge. https://doi.org/10.4324/9780203930366

Dwivedi, K. S. L. (2003). Saarc Challenges and prospects. Retrieved from http://shodhganga.inflibnet.ac.in/bitstream/10603/66002/12/12_chapter\%207.pdf

Feraru, A. S. (2015). ASEAN Decision Making Process: Before and After the ASEAN Charter, Asian Development Policy Review, 4(1), 26-41. https://doi.org/10.18488/journal.107/2016.4.1/107.1.26.41

Ginsberg, J. (2009, Feb. 26). Backgrounder: ASEAN: The Association of Southeast Asian Nations. The New York Times. Retrieved from https://archive.nytimes.com/www.nytimes.com/cfr/world/slot3_20090225.html

Grover, V. (ed.) (1997). Encyclopedia of SAARC Nations, Deep \& Deep Publications, New Delhi, p.627.

Gupta, B. S. (1983, Aug. 31). The Indian Doctrine, India Today, p. 20.

Hafeez, M. (2016). 2016 SAARC Summit: Future of Regional Cooperation in South Asia, 
Strategic Studies, $\quad 36(3), \quad 38-57 . \quad$ Retrieve from http://issi.org.pk/wp-content/uploads/2016/11/3-Mahwish_Hafeez_SS_Vol_36_No.3_2016.pd $\mathrm{f}$

Hasan, A. A., Malik, M. I., Khan, H. H., \& Anwar, M. (2017). Getting Our Act Together: A Case of Improving Trade Facilitation in South Asia. Punjab Economic Research Institute, Lahore. from http://www.ndtv.com/india-news/india-pulls-out-of-saarc-summit-in-islamabad-1467221

Heiduk, F. (2016). Indonesia in ASEAN Regional Leadership between Ambition and Ambiguity, (SWP Research Paper 6). German Institute for International and Security Affairs.

Leifer, M. (1983). Indonesia's Foreign Policy. London: Allen \& Unwin.

Majid, A. (2011). Performance of SAARC as a regional organization in comparison with ASEAN and Eco (Doctoral Dissertation, Centre for South Asian Studies, University of Punjab, Pakistan). Retrieved from http://prr.hec.gov.pk/jspui/bitstream/123456789/1361/1/2059S.pdf

Ministry of Foreign Affairs, Singapore (2014, Aug. 08). MFA Press Statement: The $47^{\text {th }}$ ASEAN Foreign Ministers Meeting and related meetings, Nay Pyi Taw, Myanmar. Government of Singapore. Retrieved from https://www.mfa.gov.sg/content/mfa/overseasmission/asean/press_statements_speeches/2014 /201408/press_20140808.html

Nahar, E. (1991). SAARC, problems and prospects. Sehgal Publishers Service. Retrieve from http://shodhganga.inflibnet.ac.in/bitstream/10603/66002/12/12_chapter\%207.pdf

Pattanaik, S. S. (2006). Making Sense of Regional Cooperation: SAARC at Twenty. Strategic Analysis. 30(1), 139-160.

Rahman, S. S. (2011). 'Same but different?':Comparing the ASEAN and SAARC Frameworks, (ISAS working papers No-123). Institute of South Asian Studies, Singapore.

Reza, A. S. M. (2016). India and SAARC: 'Same Bed, Different Dreams'? Osaka University Knowledge Archive, 20(2), 77-92. http://hdl.handle.net/11094/60479

SAARC (n.d.). South Asian Association of Regional Organization. SAARC Charter. Retrieved January 05, 2019, from http://saarc-sec.org/saarc-charter

SAARC summit "postponed indefinitely". (2016, Oct. 1). The Hindu. Retrieved from https://www.thehindu.com/news/international/SAARC-summit-quotpostponed indefinitelyquot/article15419427.ece

Sally, R. (2010). Regional economic integration in Asia: The track record and prospects. Ecipe Occasional Paper, 2. Retrieved from http://www.ecipe.org/publications/ecipe-occasional-papers/regional-economic-integration-inasia-the-track-record-andprospects/PDF

Severino, R. (2006). Southeast Asia in search of an ASEAN community: Insights from the former ASEAN secretary-general. Singapore: Institute of Southeast Asian Studies. 
https://doi.org/10.1355/9789812305671

Shaheen, I. (2013). South Asian Association for Regional Cooperation (SAARC): Its Role, Hurdles and Prospects. IOSR Journal of Humanities And Social Science (IOSR-JHSS), 15(6), 01-09. https://doi.org/10.9790/0837-1560109

Shee, P. K. (1977). A decade of ASEAN, 1967-1977. Asian Survey, 17(8), 757-758.

Siddiqi, H. G. A. (2015, Mar. 11). Bangladesh in regional and interregional blocs. The Daily Star.

http://123.49.46.157/bitstream/handle/10361/4088/The\%20daily\%20star.pdf?sequence=1

Sukma, R. (2012). Indonesian Foreign Policy: Domestic Politics and International Posture: Constraints and Possibilities. In R. Anthony (Eds.) Indonesia Rising: The Repositioning of Asia's Third Giant (pp. 79-85.). Singapore: Institute of Southeast Asian Studies. https://doi.org/10.1355/9789814380416-011

Thambipillai, P., \& Saravanamutta, J. (1985). ASEAN Negotiations: Two Insights. Singapore: Institute of Southeast Asian Studies, p. 3.

Thornton, T. P. (1991). Regional organizations in conflict management. The Annals of the American Academy of Political and Social Science, 518(1), 132-142. https://doi.org/10.1177/0002716291518001011

Tuan, H. A. (1996). ASEAN Dispute Management: Implications for Vietnam and an Expanded ASEAN. Contemporary Southeast Asia, 18(1), 61-80. https://doi.org/10.1355/CS18-1D

World Bank. (2018a, September 19). South Asia can Triple Regional Trade by Removing Trade Barriers. Retrieved from https://www.worldbank.org/en/news/press-release/2018/09/19/south-asia-can-triple-regional-t rade-by-removing-trade-barriers

World Bank. (2018b, September 24). South Asia Should Remove Trade Barriers for Mutual Economic Gains: New World Bank Report, Retrieved from https://www.worldbank.org/en/news/press-release/2018/09/24/south-asia-remove-trade-barrie rs-mutual-economic-gains-report

World Bank. (2018c, October 9). Realizing the Promise of Regional Trade in South Asia. Retrieved from http://www.worldbank.org/en/news/feature/2018/10/09/realizing-the-promise-of-regional-tra de-in-south-asia.

\section{Copyright Disclaimer}

Copyright for this article is retained by the author(s), with first publication rights granted to the journal.

This is an open-access article distributed under the terms and conditions of the Creative Commons Attribution license (http://creativecommons.org/licenses/by/4.0/). 